\author{
Alessandro VITALE \\ University of Milan \\ alessandro.vitale@unimi.it
}

\title{
ETHNOPOLITICS AS CO-OPERATION AND COEXISTENCE: THE CASE-STUDY OF THE JEWISH AUTONOMOUS REGION IN SIBERIA
}

ABSTRACT It would be a mistake to assume that ethnopolitics is only a matter of confrontation between different ethnic groups. On the contrary, there is a range of examples where it is pursued in a spirit of compromise and co-operation. One of them is the case of the Jewish Autonomous Region of Birobidzhan, in Post-Soviet Russia. Often ethnic groups realize that co-operation and cultural coexistence are more profitable than conflict. Beginning in 1928 the Soviet Union set aside a territory the size of Belgium for Jewish settlement, located some five thousands miles east of Moscow along the Soviet-Chinese border. Believing that Soviet Jewish people, like other national minorities, deserved a territorial homeland, the regime decided to settle an enclave that would become the Jewish Autonomous Region in 1934. In fact, the establishment of the JAR was the first instance of an officially acknowledged Jewish national territory since ancient times. But the history of the Region was tragic and the experiment failed dismally. Nevertheless, Birobidzhan's renewed existence of today is not only a curious legacy of Soviet national policy, but after the break-up of the Soviet Union and the definite religious rebirth, represents an interesting case-study in respect to interethnic relations.

Key words: Jewish Autonomous Region (JAR), post-Soviet Russia, Birobidzhan, interethnic relations, Siberia 


\section{INTRODUCTION}

It would be a mistake to assume that ethnopolitics is only a matter of confrontation between different ethnic groups. It cannot be reduced to the mere study of conflict alone. On the contrary, there is a range of examples where ethnopolitics is pursued in a spirit of compromise and co-operation. In other words, beside the "dark side" of ethnopolitics in some cases it is possible to find its "co-operational forms": often ethnic groups realize that cooperation and cultural coexistence are more profitable than conflict. This is exemplified by, among others, the case-study of the Jewish Autonomous Region (JAR) of Birobidzhan, in post-Soviet Russia. This case-study is quite interesting under many aspects and particularly in terms of interethnic relations analysis, interethnic cooperation, coexistence and ethnopolitics.

In the Russian Far East there can still be found a "Jewish enclave". Beginning in 1928 the Soviet Union set aside a territory larger than Belgium and Holland combined for Jewish settlement. It was located some five thousand miles east of Moscow between the $48^{\text {th }}$ and $49^{\text {th }}$ parallels north latitude (where the climate and conditions are similar to Ontario and Michigan), along the Trans-Siberian Railway and the Soviet-Chinese border.

Believing that Soviet Jewry, like other national minorities, deserved a territorial homeland, the regime decided, following the Stalinist theory of nationalities, to build a Jewish enclave that in 1934 would become the Jewish Autonomous Region (JAR, in Yiddish: Yidishe Avtonomne Gegnt), popularly known as Biro-bidzhan, reflecting the name of the Region's capital city, located on the rivers Bira and Bidzhan. The Soviet political class hoped that Birobidzhan would serve as an alternative to Palestine by fostering the development of a secular, non-religious and Yiddish Jewish ${ }^{1}$ culture rooted in Socialist principles, in order to build a future Jewish-socialist utopia. The idea was to create a "new Zion" - as a counterweight to Palestine - where a "proletarian Jewish culture" based on the Yiddish language could be developed. The settlement of the JAR

Yiddish, rather than Ivrit (Hebrew, תירבע) - considered the tongue of the bourgeois Zionist - was chosen as the "regional language" in open contrast with Ivrit. The building of a "Yiddishland" raised many hopes among Jewish people that had suffered from pogroms and persecutions for a long time before 1917, especially in the western part of the Russian Empire. See: M. Kadyshevich, Birobidzhan - strana bol'shich vozmozhnostej, Mosca 1931; M. Alberton, Birobidzhan, die Judenrepublik, Leipzig 1932; L. Lvavi, Hityashvut Hayehudim Bebirobijan. The Jewish Colonization of Birobidzhan, Jerusalem 1965; A. Kagedan, The Formation of Soviet Jewish Territorial Units, 1924-1937, Ann Arbor 1987; idem, Soviet Zion. The Quest for a Russian Jewish Homeland, Basingstoke 1994; J.J. Stephan, A Far Eastern Jewish Homeland, Stanford 1994; A. Vitale, El Primer Israel. La increible historia del nacimiento y desarrollo de una región autónoma en un confin siberiano. De cómo el pueblo hebreo se sobrepuso a un experimento de Stalin, trans. by V. Mascioni, Buenos Aires 2007 (Conversaciones. Monde Diplomatique "El Diplo’, 27); H.F. Srebrnik, 'Birobidzhan: A Remnant of History. The Jewish Autonomous Region in the Russian Far East', Jewish Current (2006); E. Maroney, The Other Zions. The Lost Histories of Jewish Nations, Lanham (MD) 2010; A. Polonsky, The Jews in Poland and Russia, Vol. 3: 1914-2008, Oxford 2011 (Littman Library of Jewish Civilization); A. Nivat, La République juive de Staline, Paris 2013; Midrasz, No. 6: Birobidzhan wczoraj i dzis' (2014). 
was meant to counter both Zionism and religious Judaism by building an atheist, Soviet version of Zion. ${ }^{2}$ Thousands of Soviet Jews flooded into the area, some fired with the enthusiasm to build a new society, others merely hungry and looking for a chance to improve their living conditions and to change their way of life. Even many American, Argentinean and other Jews from all over the world escaped the Great Depression to start their "new life" in the Jewish Socialist utopia. In fact, the establishment of the JAR was the first instance of an officially acknowledged Jewish national territory since ancient times. ${ }^{3}$ Consequently, Israel is not the only official Jewish homeland in the world. But, as well known, the history of the Region was tragic and the experiment of a "first Israel" failed. Nevertheless, the region's "Jewish" status has survived incredible deprivations and persecutions, Stalin's purges and the destruction of the local cultural heritage, the destruction of libraries ${ }^{4}$ and so on. Birobidzhan's continued and renewed existence and the revival of Jewish life and culture in the post-Soviet JAR are not only a curious legacy of Soviet national policy but, after the break-up of the Soviet Union, represent an interesting case-study in respect to the study of some challenging geographic problems and interethnic relations.

Fig. 1. The geographical location of the JAR

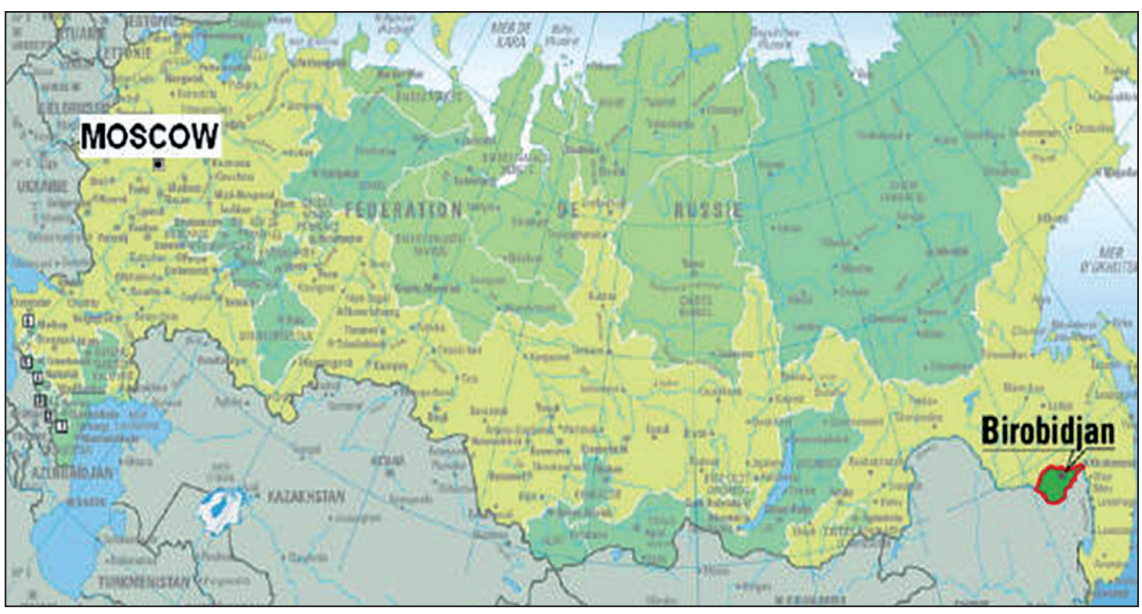

Source: Author's own elaboration

The JAR still exists as a political entity in Russia and is still functionally considered a "Jewish region", although few Jews now live there. Nowadays the Region's economic prosperity, combined with its renewed Yiddish heritage, helps to create a soil

2 A.L. Rovner, In the Shadow of Zion. Promised Lands Before Israel, New York 2014, p. 8.

3 The JAR was the first and the only (administrative) territorial unit of the Jewish people not only in the USSR but also in the world. Israel was established by the UN only twenty years later, in 1948 .

4 The purges even led to the burning of the whole Judaica Collection in Birobidzhan's local libraries. In 1948 Soviet bureaucrats closed the last Jewish school in Birobidzhan. 
for a Jewish local future ${ }^{5}$, but remembering that citizenship of a national minority shall be a matter of free personal choice and no disadvantage shall result from the choice of such membership. The coexistence between Jewish, Orthodox, and Muslim religions and cultures is a remarkable and evident example of the spontaneous and "unplanned" co-operative side of ethnopolitics.

\section{A CONTROVERSIAL GEOGRAPHIC AND ADMINISTRATIVE PLACE}

The Jewish Autonomous Region (Oblast) was meant as an administrative tool to settle the "Jewish Question" in Stalin's Soviet Union. In the 1920s the Soviet government made several efforts to build a Jewish homeland in Ukraine and Crimea but the projects met local resistance and were soon abandoned. ${ }^{6}$ In March of 1928 the government decided to populate an area in the Amur River Basin for "settlement by working people of Jewish Nationality". Stalin wrote in 1913 that nations without territory were "not real". Stalin's theory of the "National Question" held that a group could be a "nation" only if its members had a territory, and since there was no Jewish territory, per se, the Jews were not a nation and did not have national rights. Moreover, in the 1920s the Party determined that the Jewish economic life was "ideologically suspect". In fact, the Jews were at the same time an extra-territorial national minority, a religious community in an atheist state, and an ethnic group on the brink of assimilation into Sovietism. Jewish communists argued that the way to solve this ideological dilemma could be to settle a Jewish territory and build a "Soviet Jewish homeland". Basically, the Birobidzhan project was at the same time also coherent with the objectives of Jewish nationalism known as "territorialism", which preached the building of a Jewish political community in a suitable territory anywhere in the world. ${ }^{8}$ At any rate, Stalin and the Soviet political class wanted to keep the Jews as far away from the political centre of the Union as possible. The government and the KOMZET (the Committee on Land Settlement of the Working Jews) decided to create a "homeland" for compact moving of the Jews, adapt-

5 Jewish culture was revived here much earlier than elsewhere in the Soviet Union. In the last twenty years Jewish culture and Yiddishkait have started to revive. There are new extensive links between the JAR and Israel, despite a long time of problems and disputes, Jewish life is reviving both in quantity and quality. H.F. Srebrnik, 'Birobidzhan...'

6 In 1928 Jews had deep roots in the Western part of the Soviet Union, in Ukraine, Belarus and Russia. In fact, initially it was suggested that they be moved into a new "Jewish Soviet Republic" projected for the Crimean Peninsula or Ukraine, but the projects were abandoned because of the hostility of non-Jews against Jewish people in those regions of the Union. Z. Gitelman, 'The Evolution of Jewish Culture and Identity in the Soviet Union' in Y. Ro'i, A. Berker (eds.), Jewish Culture and Identity in the Soviet Union, New York 1991.

7 A nation, according to Stalin, was a historically constituted, stable community of people, formed on the basis of a common language, territory, economic life, and psychological makeup manifested in a common culture. J.V. Stalin, Marxism and the National Question (1913), Moscow 1945.

8 Territorialism was an attractive option for many Jewish intellectuals. A.L. Rovner, In the Shadow of Zion..., pp. 8-9. 
ing the Jewish communities to agriculture. By devoting resources and land to the Jews, the government tried to attract Jewish money and settlers from abroad and even from all over the world: America, Argentina, and Europe.' Settling and developing a region on the border with China would at the same time be a strategic step in strengthening Soviet control over the whole area of the Soviet far East and its natural resources (iron, fish, timber, tin, graphite and gold). This territory, annexed by Imperial Russia in 1858, was also selected in order to buffer the Soviet Union from Chinese and Japanese expansionism. In 1934 the Region was given the status of "autonomous region" (avtonomnaja oblast'), and, encompassing 36,000 square km, it was already larger than Palestine.

Jewish settlements were created in small villages. But during the time of the Great Purges and later, after WWII, Jewish people became an object of persecution and Jewish Institutions were shut down. Thousands of Jews were imprisoned and killed. In the Jewish Autonomous Region migration spontaneously stopped. As a result, the Region became "Autonomous" and "Jewish" only in name.

In the late 1980s, less than 5\% of inhabitants were Jewish and in Birobidzhan there was only one small synagogue. However, in the last few years the ethnic and socio-cultural composition has changed as some residents are now less afraid to announce their Jewish background. Therefore, both the Yiddish and modern Jewish cultures have experienced a rebirth after the decision of a significant number of Jews to come back to the JAR from Israel. The former Vice-chairman of the Regional Government, Valery Gurevich (Jewish, like many of the Region's elected officials), denied that the Region is no longer Jewish. ${ }^{10}$ Nowadays in the Region there is an evident rebirth of spontaneous cooperation and close relations between religions, schools, institutions, in the absence of interethnic tensions and conflicts. The cooperation consists, first of all, in the realization of joint charitable actions and cultural events. Birobidzhan's children (Jews and non-Jews) learn together about Jewish tradition. The local youth has never known what anti-Semitism or anti-Judaism are. Children grow up, play and learn together in schools where Jewish culture is widespread. Despite Soviet persecution, Jewish people and non-Jews have lived in the Region for over sixty years in peace. Therefore this case-study may be important for ethnic research beyond the case of the JAR and for the development of policy strategies for managing ethnic conflicts, cultural, and religious diversities. Jewish culture has spontaneously arisen from the ruins of Stalin's incredible experiment.

9 Historians have argued that in this conjunction, the treatment of the Jews in the Soviet Union was a feather on the Red cap and the endeavour to create a national Jewish administrative unit would be bound to create a measure of sympathy. B.Z. Goldberg, The Jewish Problem in the Soviet Union. Analysis and Solution, New York 1961, p. 170. See also B.L. Bruk, Birobidzhan, Moscow 1928; E. Bugaenko, Na beregu Amura. 50 let Evrejskoj Avtonomnoj Oblasti, Moscow 1984; B. Arnovitz, 'Zion in Siberia,' Survey, Vol. 29, No. 3 (1985); A. Kuchenbecker, 'Ein "Rotes Palästina” im Fernen Osten der Sowjetunion - die Verbannung einer Idee. Die Auseinandersetzungen um ein autonomes jüdisches Siedlungsgebiet in der frühen UdSSR', Archiv für Sozialgeschichte, No. 37 (1997).

10 A. Vitale, La Regione ebraica in Russia. Birobidzhan, la prima Israele, Lugano 2005, p. 160 (Attualità e Studi). 


\section{THE DEVELOPMENT OF THE JAR AND THE COLLAPSE OF THE SOVIET UNION}

After the first wave of immigrants, over the next ten years a total of 35,000 Jews came to this area, mixing with the Cossacks, Ukrainians, and the Koreans (about 27,000) already living there. The central government started relocating thousands of Jews to the area, using the Trans-Siberian railway. Today, the 5,000 mile journey from Moscow to Birobidzhan takes six days; the same journey took, at that time, more than a month. Birobidzhan was built by artisans and craftspeople, descendants from the impoverished shtetls of the Western part of the Russian Empire, as members of a massive, voluntary immigration. But there were large tracts of swampland and marshes. The early conditions of living were terrible and so crude that some settlers lived in zemlyanki, huts of sod and thatch, built over a hole in the ground. The majority of settlers were not familiar with agriculture. Little was done to prepare them and many of them had never worked the land in their lives. The government totally failed to provide decent housing, food, medical care and working conditions. A severe flood ravaged the region and some collective farms had to be started anew. Nevertheless, despite a new wave of emigration from the Region (many settlers stayed there very briefly), some immigrants decided to remain, building the settlements of Waldheim, Tikhonkaya (later Birobidzhan), Amurzet and others in the South of the Region. Jewish settlements were created in small villages (Birofeld, Danilovka, etc.) that connected the Trans-Siberian railway with the Amur River valley.

The perspective of the revival of a potentially autonomous Jewish political unity even found response abroad, first of all among the American Diaspora. Ambijan, ${ }^{11}$ Agro-Joint and ICOR (Idishe Kolonizatsy Organizatsye; Association for Jewish Colonization in the Soviet Union, born in 1924 in America) made huge contributions to the project. ${ }^{12}$ The ICOR rendered free material help to the settlers. The apparent revival of a sovereign Jewish territory as an autonomous entity stimulated the influx of immigrants from abroad: they sincerely believed that the Soviet Union could become a democratic people's state and - in 1929 - the only true solution to the Great Depression and the "great crisis of capitalism" ${ }^{13}$ Almost 700 people from Lithuania, Argentina, Latvia, France, Germany, Belgium, USA, Poland, and even several hundred from Palestine ${ }^{14}$, went to the JAR. Many left-wing Jews and pro-Soviet organizations in the United States, Canada, and elsewhere closely followed events in Birobidzhan. Many of

11 Albert Einstein served as honorary President of the American Birobidzhan Committee (Ambijan).

12 H.F. Srebrnik, 'Birobidzhan...; idem, Jerusalem on the Amur. Birobidzhan and the Canadian Jewish Communist Movement, 1924-1951, Montreal 2008 (McGill-Queen's Studies in Ethnic History, Ser. 2, 25); idem, Dreams of Nationhood. American Jewish Communists and the Soviet Birobidzhan Project, 1924-1952, Boston 2010 (Jewish Identities in Post-Modern Society).

13 A government-produced Yiddish film called Seekers of Happiness tells the story of a Jewish family that fled the Great Depression in the United States to make a new life for itself in Birobidzhan.

14 The impact of the propaganda was so powerful that several thousand Jews immigrated to Birobidzhan 
them sent money and machinery, while perhaps one thousand to two thousand Jews decided to move to the purported "Soviet Zion" during the 1930s.

By 1934, 22,000 Jews had come to the JAR, a little over 5,000 had stayed to work and live, most residing in kolkhozes. They did their best to preserve a secular Yiddish culture through theatres, schools, clubs and libraries. In the mid-1930s, Birobidzhan was hailed as a growing centre of Yiddish culture, Jewish artists were encouraged to settle there and as the Jewish population grew, so did the impact of Yiddish culture on the Region. ${ }^{15}$ The Russian population and even Cossacks, contrary to what happened in the western part of the Empire, ${ }^{16}$ gave them all possible support. There were no tensions between the Jews and the Cossacks or with the community of ethnic Koreans that settled those lands after escaping Japanese labour camps in Manchuria. Many villages and collective farms sent instructors whose purpose was to train settlers in agriculture. In total, from 1928 up to 1933, 22,300 persons migrated to the Region. As a result, multinational culture and art developed rapidly. Several regional newspapers and literary, art and political magazines were issued. Some magazines published the works of the largest Soviet Jewish writers and poets. During the Region's first decade of existence, along with Russian, Yiddish became the official language of the Region. In 1935, following a government decree, all the governmental and party documents appeared in both Russian and Yiddish.

Despite efforts to encourage Jewish people to resettle in the Region during the first decade of its existence and again after the end of World War II, the Region failed to attract Jewish people. By 1939 just under 18,000 of the Region's approximately 109,000 inhabitants were ethnically Jews. Soviet Jews were more inclined to move to one of the main cities in the Western Soviet Union, such as Minsk, Leningrad, Kiev, Moscow, or Odessa than to uproot themselves to the marshes of Birobidzhan, where education and job opportunities were limited. Moreover, as the Soviet Union transformed into a totalitarian State ruled by Stalin's iron fist in the late 1930s and purges began to sweep the country, the JAR's leadership was decimated and accused of ideological heresies. Essentially, the Kremlin's attitude toward Jews turned hostile and the regime clamped down on the Jewish settlement. Less than 10 years after the creation of the Jewish Autonomous Region, Stalin's regime began to destroy the local Jewish culture. Yiddish books were burnt, Jewish schools and the synagogue were closed down. Thousands of Jews were imprisoned and killed. The government dismantled agencies dealing with Jewish resettlement, shut down many cultural and social Jewish institutions, eliminated Jewish intelligentzija and promoted cultural assimilation of the Jews. While retaining Yiddish as an official language and maintaining the fiction that Birobidzhan embodied

from outside the Soviet Union, including several hundred from Palestine who had become disillusioned with the Zionist experience.

15 I. Emiot, The Birobidzhan Affair. A Yiddish Writer in Siberia, trans. by M. Rosenfeld, Philadelphia 1981, p. XV.

16 During the early part of the $20^{\text {th }}$ Century, the Cossacks, ancient defenders of the Russian Empire known for their military prowess, conducted vicious pogroms against Jews. After the Revolution, the last remnants of their autonomy disappeared. 
the national and cultural aspirations of Soviet Jewry, the Soviet regime nonetheless stifled the emergence of Jewish culture and society.

Since the first days of WWII the economy of the Region shifted to war production. Consequently, even if not intentionally, the Region saved Jewish people from starvation and from Nazi persecutions for the third time ${ }^{17}$. In the wake of WWII, in 1946 and 1947, the Kremlin revived Jewish migration to Birobidzhan and aided in the restoration of Yiddish culture. The three post-war years, when the country had been destroyed, were the years of the best prosperity of local Jewish culture and the industrial building of the local civil society. Another wave of Jewish immigrants flooded the Region.

During WWII anti-Semitism was one of the reasons for the increase in solidarity among the Jewish people. Germany's aggression toward the Jewish people during the war intensified national feeling among them. This increased the interest of the world Jewry in the JAR..$^{18}$ Between 1946 and 1948, perhaps as many as 10,000 Jews moved to the JAR. During 1947 and 1948 twelve special trains brought approximately 6,500 Jewish settlers, primarily from Ukraine, to the JAR. By the end of 1948, when the State of Israel was established, 30,000 Jews lived in Birobidzhan. In the streets of the city, of many villages and settlements Yiddish was heard as often as Russian. Soviet control over the area became less stern. Jewish cultural life was resuscitated and a synagogue was opened in 1947. But the emergence of government-sponsored anti-Semitism during the last years of Stalin's life destroyed any hope that Birobidzhan could develop into a centre of Soviet Jewish life. The number of Jewish demands for expatriation documents to Israel increased and Stalin brutally changed the policy towards Jewish people inside the country. All traces of Jewish culture in the JAR were wiped out, with the only exception being the newspaper Birobidzhaner Stern, in Yiddish, and radio programming, which consisted of virtual translations of Pravda. Yiddish schools, theatres and the synagogue were closed once again. The practice of Judaism was discouraged and the teaching of Yiddish was curtailed. The revival of the "Birobidzhan idea" ended with the Doctor's plot (1952), and Stalin's second wave of purges, shortly before his death. Although the Jewish people used to constitute almost the majority in the Region, their number started to decline inexorably. In the ensuing years the idea of an autonomous Jewish region in the Soviet Union was all but forgotten. ${ }^{19}$

By the time the USSR collapsed in 1991 and when Russia and Israel established

17 The first was the settlement as an escape from the western part of the Soviet Union with its dramatic problems in the 1920s and the second happened at the time of Holodomor, the intentionally provoked famine in Ukraine (1932-33), with approximately 7 million horrible deaths. See R. Conquest, The Harvest of Sorrow. Soviet Collectivization and the Terror-Famine, New York 1986.

18 Einigkeit, the Yiddish newspaper published in Moscow, often referred to the Jewish immigrants' desire to take part in building the future of the Jewish Region. The Jewish Anti-Fascist Committee played a major role in attracting the attention of government officials to the Birobidzhan Project. I. Emiot, The Birobidzhan Affair..., pp. 2-3.

19 Even those Jews who really believed in a future Jewish Republic and contributed to the development of Birobidzhan were executed during the purges of the 1930s and 1940s. The purges not only liquidated the Jewish officials and intellectuals, but also erased basic elements of the Jewish nationality and culture. 
diplomatic relations, most of remaining Jewish population left for Israel and Germany. About 150,000 inhabitants left the Region for Israel at the beginning of the 90s. Today, the remaining Jews constitute less than $3 \%$ of the inhabitants, but in fact it is uncertain how many Jews live in the Region. Probably, of the current population of over 200,000 in the JAR, no more than a few thousand residents are Jewish. However, there has been a noticeable revival of Jewish life. Yiddish is once again taught in public schools and still remains one of the official languages of the Region. Jewish culture and literature are studied in all of the JAR's schools, where a mix of Jewish and gentile, including Korean and Chinese, children study. Everyone is interested in Yiddish and Judaism. Many non-Jewish parents say that since they live in the JAR, they want their children to know about Jewish history, language and culture. The Birobidzhan National University is unique in the Russian Far East. The basis of the training course is the study of the Hebrew language, history and classic Jewish texts. The newspaper Birobidzhaner Stern, one of the few of its kind all over the world, has been published continuously since the early 1930s, except when WWII interrupted its publication for several years (it was shut down by a decree), even if some efforts were made to "russify" Yiddish culture. ${ }^{20}$ Additionally, Yiddish radio and television programming still operates. In the early 1990s offices displayed plaques both in Russian and Yiddish, despite the fact that Jewish people numbered no more than several thousand inhabitants. However, Yiddish culture flourished, attracting more than 40,000 Jews from all over the world. The JAR now hosts an International Festival of Jewish culture, an annual event since 1988. The JAR's economy, based on mining, agriculture, lumber, and light manufacturing, is doing well, in part due to the intensive exchange with Chinese people living beyond the Amur border. The JAR's gross regional product has reportedly increased by $50 \%$ since 2000. Its well-developed industrial and agricultural sectors and its rich resources, namely minerals and building materials, are in great demand with the "booming" export of raw materials to China. Cattle and poultry are raised on the rich grassland, and an abundance of nectar-producing plants creates favourable conditions for beekeeping. ${ }^{21}$ Water is also abundant in the Region. The Amur River connects the JAR to the Pacific Ocean. The Trans-Siberian railway links the Region with Russia, East Asia, and the Pacific. In the last few years the ethnic and socio-cultural composition has changed significantly as some residents are now less afraid to announce their Jewish background. The Region has also experienced a rebirth of both of the Yiddish and modern Jewish cultures after the decision of a significant numbers of Jews to come back to the JAR from Israel. ${ }^{22}$

20 The most notable of these was an attempt to replace the Hebrew alphabet used for writing Yiddish with the Cyrillic alphabet. The Yiddish section of the Birobidzhaner Stern is edited by Elena Sarashevskaja, who is not Jewish. She learned Yiddish and realized that this ancient language Is not only a language, it is about Jewish history and literature, our culture.

21 H.F. Srebrnik, 'Birobidzhan...', p. 18.

22 A. Vitale, 'Birobidzhan: la "Prima Israele”, Galatea - European Magazine (2005); idem, La Regione ebraica in Russia. Birobidzhan, la prima Israele, Lugano 2005 (Attualità e Studi); idem, El Primer Israel... 
Currently, something unusual is happening: many Jews are moving to Birobidzhan every year. The Region's autonomy led to the creation of regional and federal bodies of executive authority. But what is more important, nowadays in the Region, in the absence of interethnic tensions and conflicts, evident spontaneous cooperation and close relations between religions, schools, institutions can be observed. The cooperation consists, first of all, in the realization of joint charitable actions and cultural events. Birobidzhan's children (Jews and non-Jews) learn together about Jewish tradition. The local youth has never known what anti-Semitism is. They may discover it (with great surprise and unforeseen frustration) only studying and moving to the western part of Russia. Children grow up, play and learn together in schools where Jewish culture is widespread. Despite Soviet persecutions, Jewish people and non-Jews have lived in the Region for over sixty years in peace. Therefore this case-study may be important for ethnic research beyond the case of the JAR and for the development of policy strategies for managing ethnic conflicts, cultural, and religious diversities.

\section{DEMOGRAPHIC PROBLEMS, IDENTITY, COEXISTENCE}

According to the 2010 Russian census, there were only 1,628, mostly older, Jews living in the region, out of a total population of around 167,000. The official figures were: 160,185 ethnic Russians (92.7\%), 4,871 ethnic Ukrainians (2.8\%), 1,182 Belarusians (0.62\%), and 1,628 ethnic Jews (1\%). According to a 2012 official survey, $22.6 \%$ of the population of the Jewish Autonomous Oblast adheres to the Russian Orthodox Church, 9\% are unaffiliated generic Christians, 6\% adheres to other Orthodox Churches. Judaism is practiced by $0.2 \%$ of the population. In addition, $35 \%$ of the population deems itself to be "spiritual but not religious", 22\% is atheist, and 5.2\% follows other religions or did not give an answer to the question.

The leading position among religions belongs to Russian Orthodox Church of the Moscow Patriarchy. Two Jewish communities also work actively. The Birobidzhan Jewish religious community "Frejd" was created in July 1997. There is close cooperation between Orthodox parishes and the Birobidzhan Jewish cultural and religious communities and now also between the main groups and the Muslims. Orthodox parishes donated many financial contributions for the building of the synagogue. The immigration of Muslim people from Central Asia to the JAR has consistently increased since 2008. The Jewish community has created good conditions of religious activity and cooperation for Muslims. The coexistence with Muslims and mutual respect is currently the most challenging and interesting development of the JAR.

Nowadays, inhabitants of the Region believe that there is a real chance that a thriving Jewish community could be established in Birobidzhan. Although the city's Jewish population - depleted by the large aliyah wave (emigration to Israel) of the 1990s - hovers between 2,000 and 6,000, the Region's economic prosperity, combined with its Yiddish heritage and return from Israel, help to create rich soil for a Jewish future. Even if there's still great confusion between Birobidzhan's Yiddish heritage, which is both lin- 
guistic and cultural, and the Jewish practice that rabbis and foreign Jewish organizations are trying to encourage, the rebirth of religious activity in the Region is remarkable. Only recently have people begun to rediscover its Jewish roots. In 2003 a rabbi moved to the Region from Israel and a new Synagogue was built. Jewish people in the Region have continued to mark Jewish holidays, and the older people remember their Yiddish and Jewish traditions, which are taught in public schools not as Jewish exotica, but as part of the Region's "national heritage". Many people in the Region (even of different ethnic origins) discover their Jewish roots, and embrace them. Ten years ago, many of those who left didn't want to proclaim themselves as Jewish. But nowadays people define themselves by Jewish characteristics and talk about how their grandmothers and great-grandmothers practiced Jewish faith. The Jewish community in the Region has a more solid base than in 1995 and a greater sense of permanence. Jewish children learn about their history and traditions in summer camps. Consequently, a Jewish cultural revival is under way. Essentially, the Region has retained its Jewish identity despite emigration. Not everyone who moved to the Holy Land decided to stay in Israel forever. ${ }^{23}$ Some Jews are moving from Israel to Birobidzhan today because of an intense sense of strangeness in Palestine and homesickness for the magnificent wildlife of Siberia. This aspect is not surprising. Eric Maroney's recent work ${ }^{24}$ demonstrates that, from ancient times to the present, the Jew's ability to create homelands for themselves in regions far from their imagined point of origins has been an important - if overlooked - part of their history.

\section{DIVERSITY-MANAGEMENT AND PRESERVATION OF PACIFIC INTERETHNIC RELATIONS IN THE JAR}

The most interesting characteristic and unique feature of the Jewish Region is, in my opinion, the formation and the consolidation of local identity of the regional kind that comes directly from its history. As Milton J. Esman wrote: Ethnic identity can be located on a spectrum between primordial historic continuities and instrumental opportunistic adaptations. ${ }^{25}$ Even though the Jewish Autonomous Region was created in 1934 to control the Jewish component of the Soviet Union with apartheid, assimilation and fusion (the slijane nacij: the "fusion" of nationalities) between the different ethno-national components, this process did not occur. In fact, there is no cultural homogeneity or assimilation, even though many characteristics typical of different peoples living in the Region became common. The Region's inhabitants were accustomed to absorbing different cultures, taking what is better from one another for generations. This aspect intensified with the end of the Soviet period, because it became normal to declare one's Jewish nationality, or to refer to this culture, even taking advantages as in the case of immigration to Israel. This historical aspect, with the spirit given by enthusiastic descend-

\footnotetext{
23 A. Vitale, La Regione ebraica in Russia...

24 E. Maroney, The Other Zions...

25 M.J. Esman, Ethnic Politics, Ithaca 1994, p. 15.
} 
ents of the first Jewish settlers, was fundamental in the building of a superb regional identity. Coexistence among people adopting the characteristics of Jewish culture became quite normal. But the cultures in the Region remained separate. Today a cooperative behaviour dominates, one that was always stimulated by natural conditions, by the need to solve common problems typical of the Siberian region. Hence the integration that occurred in the Jewish Autonomous Region hardly resembles the one elaborated by the theorists of the assimilation. The reality of today's coexistence is the opposite of the assimilation paradigm (according to the Sociological School of Chicago of the first half of the twentieth century) that considers culture homogeneous: the most interesting fact is that ethnic identifications have not disappeared, nor even darkened. There did not occur an assumption of values, rules, and models of behaviour (seen as static and not changeable) by minorities acquired from the majority group, resulting in the loss of their ethnic distinctive characters with the fusion of differences - a process that Robert E. Park and Ernest W. Burgess considered inevitable. ${ }^{26}$ Particularly, in this case there is strong interest in the local Jewish characteristics as a unique heritage in the world, as a common point of reference, and as a source of regional and local pride. Even mixed marriages were not able to create neither an amalgam, nor assimilation. Mixed marriages were not considered dangerous for cultural reasons in the Region, as it frequently happened among Zionists living in Russia or in the Diaspora. On the contrary, those marriages have stimulated cultural life, and the enrichment of the Jewish culture of the Region. Rather there was always awareness of relevance of ethnic differences, and the differences were considered able to enrich one another. The bilingual skills, the interest for the Yiddish renaissance, schools, teaching Jewish world culture, show the vitality of these mutual relations. On the other hand, the sense of dominant insecurity, typical of the contemporary "society of uncertainty" ${ }^{27}$ is absent.

The most interesting feature is the non-existence of ethnic prejudices such as the anti-Semitism that experienced a long and dramatic history in Russia. Young people discover anti-Semitism only when they go to study in Russia's western cities or abroad but they cannot even understand the meaning of this phenomenon, which is generally very strange and quite incomprehensible for them.

The Jewish people of the Region were able to refuse the assimilation, seeking soft forms of ethno-national conscience not in contrast with multicultural coexistence, but stimulating imitation. As a result, there was a process of "approaching", ${ }^{28}$ and subsequently "adaptation". ${ }^{29}$ Ethnic groups of different origins, completely different in terms of cultural characteristics, took many aspects from other groups, producing common cultural traits. This corresponds to new approaches to the problem of integration ${ }^{30}$ :

26 R.E. Park, E.W. Burgess, Introduction to the Science of Sociology, Chicago 1921.

Z. Bauman, La società dell'incertezza, Bologna 1999 (Intersezioni, 193).

28 Yu.V. Bromley, 'Towards a Typology of Ethnic Processes', British Journal of Sociology, Vol. 30, No. 3 (1979), at <http://dx.doi.org/10.2307/589912>.

29 A.D. Smith, The Ethnic Origins of Nations, Oxford 1986, p. 34.

30 See, for example, R. Alba, V. Nee, 'Rethinking Assimilation Theory for a New Era of Immigration', 
the culture, a basic element of the people, is seen as a syncretised phenomenon in permanent evolution, as an amalgam of different influences. This is the reason why "natural assimilation", ${ }^{11}$ stemming from everyday cultural interactions, did not occur. Reciprocal "acculturation" - typical of the conceptions of the twentieth century (whether American or Soviet), and seen as a certain product of the succeeding of generations ("straight-line assimilation") - became untrue in the JAR. A "reactive ethnicity", able to stimulate the "feeling of us" against the "other", did not take form. Nowadays, the diversity-management in the JAR is based on cultural (not only Jewish) institutions that continue the old tradition of spontaneous cooperation between different ethnic groups, promoting an inherited management and way of life at the material and spiritual levels. Indeed, cooperation is evident in the meetings, in shared holidays, in common celebrations of public events, as in the case of the meaningful annual "Festival of Slavic and Jewish Culture". Innovative cultural programs continuously promote diversity-management and interethnic coexistence, based on a very interesting widespread form of Jewish "local" and "regional patriotism".

\section{A "REGIONAL PATRIOTISM"}

Interestingly, there is now a new kind of "regional patriotism" in the JAR. Indeed, the Region lacks cultural exclusivism, uniformity, discrimination, ethnocentrism, typical of every kind of nationalism, ${ }^{32}$ and the self-isolation of ethnic minorities from one another. The community developed spontaneous forms of syncretism and of mutual comprehension among different ethnic groups. ${ }^{33}$ The roots the inhabitants feel they have in common are not a product of a single identity, or the result of assimilation, but of living together with different people, of mutual respect and frequent interactions, of a common history that creates a number of links between individuals and groups. ${ }^{34}$ Moreover, the Siberian "territory of frontier" contributed to the development of strong ties with the land and the other settlers; a sort of "local patriotism", of "communitarian mythomoteur" 35 that constantly renews itself and that did not disappear in the Jewish people that moved to Israel.

The "ethnic revival" of Jewish people ${ }^{36}$ stimulated the children born from mixed marriages (contrary to what happened in the communities of Jewish people in the western part of the former Soviet Union) not to strive for assimilation but highlight each dis-

International Migration Review, Vol. 31, No. 4 (1997), at <http://dx.doi.org/10.2307/2547416>, pp. 826-874.

31 W. Connor, Ethnonationalism. The Quest for Understanding, Princeton 1994; idem, Etnonazionalismo. Quando e perchè emergono le nazioni, Bari 1995, p. 34 (Nuova Biblioteca Dedalo, 173).

32 H.-U. Wehler, Nationalismus. Geschichte, Formen, Folgen, München 2001 (Beck'sche Reihe, 2169).

33 A. Nivat, La République juive...

34 W. Connor, Ethnonationalism...; idem, Etnonazionalismo..., pp. 103-104 and 234.

35 A.D. Smith, Le origini etniche delle nazioni, Bologna 1992, p. 72 (Saggi).

36 R. Rotschild, Ethnopolitics. A Conceptual Framework, New York 1981 
tinctive characteristic of the different cultures inhabiting the Region, despite not having known their own origins for so long. The renaissance of an "active Jewish culture" (due to the religious renaissance, contrasting with the Soviet repression), and the elimination of the old contrast (of the Soviet type) between Yiddish culture and Hebraism, have also contributed to this outlook. The "active culture", ${ }^{37}$ contrary to the Jewish "passive" culture of the Soviet period ${ }^{38}$, has in fact stimulated a process of identity-building.

Judaism in Birobidzhan takes a different physiognomy toward the exclusivity of blood (descendant from mother) and religion. The non-Jewish people feel mostly culture, a sort of integral way of life, a historically-based identity, as some scholars define it ${ }^{39}$ that do not stop to the vision of current Hebraism. In this way local Hebraism managed to produce forms of cultural patterns of reference that created the base for a culture rooted in proud Jewish characteristics shared by inhabitants that became the constituent myth of local community, the identity source, and "the culture of reference". Territoriality means in this case a process of personal and collective identification and of identity-building.

Russians, Ukrainians, and Byelorussians who have reached the Region at different times and with several "waves" of immigration, consider this Region as their own and they have often described their traditions as rooted in Jewish history, which they view as their own history. Their interest in Jewish culture, habits, and everyday way of life is developing along with their interest in Yiddish language. Consequently, despite the fact that throughout the world many languages are in danger of dying out completely, Yiddish is experiencing a consistent revival.

The Jewish people of the Region do not consider themselves to be members of the world's Jewish Diaspora but regard the Region simply as one of many of the "world's Hebraism twigs". In other words, they do not feel themselves as "carriers" of a "vicarious nationalism", ${ }^{40}$ in reference to other ethno-national fragments dispersed in different parts of the world.

\section{THE DIFFICULTIES CREATED BY THE RUSSIAN POLITICAL SYSTEM}

In 2013 the Russian government announced a plan to offer US\$ 8,000 (including direct financial assistance, airline tickets, coverage of moving expenses, and health insurance) to any immigrants - who do not even have to be Russian nationals - who would be willing to relocate to the JAR. The government has expressed concern that Far East

37 Z. Gitelman, 'The Evolution of Jewish Culture...'

38 The Bolsheviks tried to build an atmosphere where the Jewish culture would be a passive one. However, the Jews were different from other ethnic groups (nations) in Russia, because their religious identity was somehow tied with their cultural identity. The aim of the assimilation was to get rid of the religious identity. However, it was obvious that the void would need to be filled with something. A secular Yiddish culture with "a socialist base" seemed to be a good approach.

39 D. Schnapper, Juifs et israélites, Paris 1980, p. 38 (Collection Idées, 423).

40 A.D. Smith, Le origini etniche..., p. 314. 
Russia is being overrun by Chinese immigrants and is menaced by an impeding "demographic disaster". However, the potentialities given by the cooperation and coexistence are still permanently obstructed by two political problems: the difficulties of a steady protection of minorities - even though they do not have typical problems of the condition of minorities - through constitutional tools (federalism, and stable self-rule), ${ }^{41}$ and the difficulty to protect the Region from strong interferences by the centralized power, which could always potentially threaten the delicate, unique balance between ethnic groups peacefully living in the Region. A possible "imbalance" stimulated by the political centralization and its obsessive planning could even encourage a new emigration of Jewish people to Israel.

The present political system of post-Soviet Russia does not offer guarantees for the development of this kind of spontaneous diversity-management in the Region, and for keeping pluralism and coexistence in place. This dangerous political system is an increasingly "apparent federal system", a still Soviet type of "façade federalism" that can at any time revoke the status of autonomy and impose hard conditions able to destroy this balance of spontaneously self-formed relations. Moreover, Russia's political order is still characterized by the national-territorial principle (the recognition - of Soviet origin - of a nationality as "owner" of a territory) in the definition of the administrative rule of republics and regions. The "cosmetic autonomies" 42 are only a mirror of a hierarchic-vertical system, federal only in appearance ${ }^{43}$ : a sort of fédéralisme inauthenthique ${ }^{44} \mathrm{de}$ facto aborted and based on the mutually-dependent? relation between centre and periphery. ${ }^{45}$ There is no parity between federal subjects and Federation, regulated by intergovernmental relations as in other federations. The JAR is even losing its financial independence. Furthermore, the post-Soviet political system is based on the idea of autonomous ethnically homogenous entities which is highly threatening for the current system. ${ }^{46}$ It is highly likely that this condition will generate new problems among local minorities. When constituent unities of federations are based on the principle of ethnic

${ }_{41}$ R. Schlesinger, Federalism in Central and Eastern Europe, Westport 1970; A.D. Smith, The Ethnic Origins of Nations, Oxford 1986; A. Vitale, 'Decentramento e autonomia: pratica e conseguenze di un mito obsoleto', Élites, Vol. 3, No. 2 (1999); H.-U. Wehler, Nationalismus...

42 See S. Nosov, 'Federalism and Anarchy in Russia Today' in A. Allain, M. Dupont, M. Hearn (eds.), Les Fédéralismes, Lille 1996, p. 208 (Collection UL3. Travaux et Recherches).

43 For this definition see L.M. Bassani, W.H. Stewart, A. Vitale I concetti del federalismo, Milano 1995 (Arcana Imperii). On the formal federal structure of Russia, redesigned by the centralization of Eltsin in 1993, see R. Sharlet, 'The Prospects for Federalism in Russian Constitutional Politics', Publius. The Journal of Federalism, Vol. 24, No. 2 (1994), pp. 115-127; and La Costituzione della Federazione russa, introd., transl. and ed. by A. Vitale, Milano 1994.

${ }_{44}$ O. Beaud, 'La Fédération entre l'Etat et l'Empire' in A. Allain, M. Dupont, M. Hearn, (eds.), Les Fédéralismes, p. 42.

45 R. Sharlet, 'The Prospects..., p. 125.

46 D.J. Elazar, Exploring Federalism, Tuscaloosa 1987; idem, Idee e forme del federalismo, Milano 1995 , p. 194 (Il Mondo Nuovo). Ethnic nationalism is the most egocentric (and irreducible) form of nationalism, the most complicated base to build a system of constitutional power-sharing. Language, religion, national myths, and so on, tend to divide the people. 
homogeneity, this raises the force of external attraction that can causes internal interethnic conflicts. ${ }^{47}$ In essence, federalism and self-rule work only without ethnic homogeneous federate entities. Jewish people have never constituted a majority in the Region but it remains in fact Jewish in terms of culture. This fact made it harder for the Jewish national and cultural institutions to dominate the Region, ${ }^{48}$ even if it is truly remarkable how much yidishkayt, in all of its variety, can endure, and Putin's efforts seemed more designed to cripple a nascent civil society rather than to help it to grow and mature. ${ }^{49}$ The increasing centralization in Russia makes centre-periphery relations particularly tense. Similarly, hierarchic administrative levels remain influenced and the dependency on centralized decisions can worsen several problems in the delicate system of interethnic relations in the JAR. In fact, the centralized government could always intervene in linguistic, cultural, and religious policy, altering the balance achieved by the original coexistence and of the specific "regional patriotism", based on a sense of cultural affinity.

Be that as it may, the fate of the Region is dependent on decision-making of the higher political level, of the centralized government, that constantly threatens the self-governing groups, and may paralyze the activity of the independent organizations of local civil society, which is fundamental for the renaissance of the Region. Only an authentic federal system with shared rule, self-rule, and limited-rule could consolidate the spontaneous formation of the interethnic coexistence within the Region. To quote Antony D. Smith: The federal solutions help to minimize the ethnic antagonisms and to assure the political recognition to territorialized entities and cultures. ${ }^{50}$ The Birobidzhan project may still have relevance today as an example of the consequences of a national planned system which, unexpectedly, produced spontaneous ethnic coexistence, despite its location within a permanently hostile political system that lacks the ability to renew itself. However, only the evolution of self-rule in an authentic federal system could protect the Region against the permanent threat of centralized power, potentially dangerous for the management and coexistence of interethnic relations.

\section{BIBLIOGRAPHY}

Abramsky Ch., 'The Biro-Bidzhan Project, 1927-1959' in Kochan L. (ed.), The Jews in Soviet Russia since 1917, London 1972.

Alba R., Nee V., 'Rethinking Assimilation Theory for a New Era of Immigration', International Migration Review, Vol. 31, No. 4 (1997), at <http://dx.doi.org/10.2307/2547416>.Alberton M., Birobidzhan, die Judenrepublik, Leipzig 1932.

47 External pressures on ethnic dissatisfied minorities can produce interethnic conflicts. I. Duchacek, Comparative Federalism. The Territorial Dimension of Politics, Lanham (MD) 1987, p. 288 (Constitutional Government in Theory and Practice).

48 B.Z. Goldberg, The Jewish Problem..., p. 226.

49 B.D. Taylor, State Building in Putin's Russia. Policing and Coercion after Communism, Cambridge 2011, p. 204

50 A.D. Smith, Le origini etniche..., p. 547. 
Allain A., Dupont M., Hearn M. (eds.), Les Fédéralismes, Lille 1996 (Collection UL3. Travaux et Recherches).

Arnovitz B., 'Zion in Siberia', Survey, Vol. 29, No. 3 (1985).

Aronson I.M., Troubled Waters. The Origins of the 1881 Anti-Jewish Pogroms in Russia, Pittsburgh 1990 (Series in Russian and East European Studies, 13).

Baron S.W., The Russian Jew under Tsars and Soviets, New York 1964 (Russian Civilization Series, 4).

Bassani L.M., Stewart W.H., Vitale A., I concetti del federalismo, Milano 1995 (Arcana Imperii). Bauman Z., La società dell'incertezza, Bologna 1999 (Intersezioni, 193).

Baumgarten J., Le yiddish, Paris 1990 (Que sais-je?, 2552). (Trad. ital.: Giuntina, Firenze 1992). Beaud O., 'La Fédération entre l'Etat et l'Empire' in A. Allain, M. Dupont, M. Hearn (eds.), Les Fédéralismes, Lille 1996 (Collection UL3. Travaux et Recherches).

Brenner F., A Moment Before. Jews in the Soviet Union, New York 1992.

Bromley Yu.V., 'Towards a Typology of Ethnic Processes', British Journal of Sociology, Vol. 30, No. 3 (1979), at <http://dx.doi.org/10.2307/589912>.

Brym R.J., The Jews of Moscow, Kiev, and Minsk. Identity, Antisemitism, Emigration, New York 1994.

Cang J., The Silent Millions. A History of the Jews in the Soviet Union, New York 1969.

Clark S.L., Graham D.R., 'The Russian Federation's Fight for Survival', Orbis. A Journal of World Affairs, Vol. 39, No. 3 (1995), at <http://dx.doi.org/10.1016/0030-4387(95)90036-5>.

Connor W., Ethnonationalism. The Quest for Understanding, Princeton 1994. (Trad. ital: Etnonazionalismo. Quando e perchè emergono le nazioni, Bari 1995 (Nuova Biblioteca Dedalo, 173)).

Conquest R., The Harvest of Sorrow. Soviet Collectivization and the Terror-Famine, New York 1986.

La Costituzione della Federazione russa, introd., transl. and ed. by A. Vitale, Milano 1994.

Duchacek I., Comparative Federalism. The Territorial Dimension of Politics, Lanham (MD) 1987 (Constitutional Government in Theory and Practice).

Elazar D.J., Exploring Federalism, Tuscaloosa 1987. (Trad. ital.: Idee e forme del federalismo, Milano 1995 (Il Mondo Nuovo)).

Emiot I., The Birobidzhan Affair. A Yiddish Writer in Siberia, trans. by M. Rosenfeld, Philadelphia 1981.

Esman M.J., Ethnic Politics, Ithaca 1994.

Gilboa Y., The Black Years of Soviet Jewry, 1939-1953, trans. by Y. Shachter, D. Ben-Abba Boston 1971.

Gitelman Z., Assimilation, Acculturation and National Consciousness among Soviet Jews, New York 1973.

Gitelman Z., 'The Evolution of Jewish Culture and Identity in the Soviet Union' in Y. Ro'i, A. Berker (eds.), Jewish Culture and Identity in the Soviet Union, New York 1991.

Gitelman Z., 'The Jews', Problems of Communism, Vol. 16, No. 5 (1967).

Gitelman Z., 'Nationality and Ethnicity in Russia and the Post-Soviet Republics' in S. White, A. Pravda, Z. Gitelman (eds.), Developments in Russian and Post-Soviet Politics, London 1994.

Goldberg B.Z., The Jewish Problem in the Soviet Union. Analysis and Solution, New York 1961. 
Goozner M., 'Jewish Culture Struggles to Revive in Russian Far East', Chicago Tribune, 30 August 1992.

Kagedan A., The Formation of Soviet Jewish Territorial Units, 1924-1937, Ann Arbor 1987.

Kagedan A., Soviet Zion. The Quest for a Russian Jewish Homeland, Basingstoke 1994.

Kochan L. (ed.), The Jews in Soviet Russia since 1917, London 1972.

Kolarz W., The Peoples of the Soviet Far East, New York 1954 (Books That Matter).

Kostyrchenko G., Out of the Red Shadow. Anti-Semitism in Stalin's Russia, Amherst 1995 (Russian Studies Series).

Kuchenbecker A., 'Ein "Rotes Palästina” im Fernen Osten der Sowjetunion - die Verbannung einer Idee. Die Auseinandersetzungen um ein autonomes jüdisches Siedlungsgebiet in der frühen UdSSR', Archiv für Sozialgeschichte, No. 37 (1997).

Levin N., The Jews in the Soviet Union since 1917: Paradox of Survival, New York 1988.

Lvavi J., Hityashvut Hayehudim Bebirobijan. The Jewish Colonization of Birobidzhan, Jerusalem 1965.

Lvavi J., 'Jewish Agricultural Settlement in the USSR', Soviet Jewish Affairs, Vol. 1, No. 1 (1971), at <http://dx.doi.org/10.1080/13501677108577083>.

Maroney E., The Other Zions. The Lost Histories of Jewish Nations, Lanham (MD) 2010.

Midrasz, No. 6: Birobidzhan wczoraj i dziś(2014).

Nivat A., La République juive de Staline, Paris 2013.

Nosov S., 'Federalism and Anarchy in Russia Today' in A. Allain, M. Dupont, M. Hearn (eds.), Les Fédéralismes, Lille 1996 (Collection UL3. Travaux et Recherches).

Park R.E, Burgess E.W., Introduction to the Science of Sociology, Chicago 1921.

Parrish M., The Lesser Terror. Soviet State Security, 1939-1953, Westport-London 1996.

Pinkus B., The Jews of the Soviet Union. The History of a National Minority, Cambridge 1988 (Soviet and East European Studies).

Pinkus B., The Soviet Government and the Jews, 1948-1967. A Documented Study, Cambridge 1984.

Polonsky A., The Jews in Poland and Russia, Vol. 3: 1914-2008, Oxford 2011 (Littman Library of Jewish Civilization).

Rapoport L., The Doctor's Plot of 1953, Cambridge (Mass.) 1991.

Rapoport L., Stalin's War against the Jews: the Doctor's Plot and the Soviet Solution, New York 1990 (The Second Thoughts Series).

Ro'i Y. (ed.), Jews and Jewish Life in Russia and the Soviet Union, Ilford 1995 (Cummings Center Series).

Ro'i Y., Berker A. (eds.), Jewish Culture and Identity in the Soviet Union, New York 1991.

Rotschild J., Ethnopolitics. A Conceptual Framework, New York 1981.

Rovner A.L., In the Shadow of Zion. Promised Lands Before Israel, New York 2014.

Schlesinger R., Federalism in Central and Eastern Europe, Westport 1970.

Schnapper D., Juifs et israélites, Paris 1980 (Collection Idées, 423).

Schwarz S.M., The Jews in the Soviet Union, Syracuse 1951.

Sharlet R., 'The Prospects for Federalism in Russian Constitutional Politics', Publius. The Journal of Federalism, Vol. 24, No. 2 (1994).

Smith A.D., The Ethnic Origins of Nations, Oxford 1986. (Trad ital.: Le origini etniche delle nazioni, Bologna 1992 (Saggi)). 
Smith A.D., The Ethnic Revival, Cambridge 1981 (Themes in the Social Sciences).

Soljénitsyne A., Deux siècles ensemble, Vol. 2: Juifs et Russes pendant le période soviétique, $1917-$ -1972, trans. by A. Kichilov, G. Philippenko, N. Struve, Paris 2003.

Srebrnik H.F., 'Birobidzhan: A Remnant of History. The Jewish Autonomous Region in the Russian Far East', Jewish Current (2006).

Srebrnik H.F., Dreams of Nationhood. American Jewish Communists and the Soviet Birobidzhan Project, 1924-1952, Boston 2010 (Jewish Identities in Post-Modern Society).

Srebrnik H.F., Jerusalem on the Amur. Birobidzhan and the Canadian Jewish Communist Movement, 1924-1951, Montreal 2008 (McGill-Queen's Studies in Ethnic History, Ser. 2, 25).

Stalin J.V., Marxism and the National Question (1913), Moscow 1945.

Stephan J.J., A Far Eastern Jewish Homeland, Stanford 1994.

Taylor B.D., State Building in Putin's Russia. Policing and Coercion after Communism, Cambridge 2011.

Thubron C., In Siberia, London 2000. (Trad ital.: Ponte alle Grazie, Firenze 2000).

Vaksberg A., Stalin against Jews, trans. by A.W. Bouis, New York 1994.

Vitale A., 'Birobidzhan: la "Prima Israele"', Galatea - European Magazine (2005).

Vitale A., 'Decentramento e autonomia: pratica e conseguenze di un mito obsoleto', Élites, Vol. 3, No. 2 (1999).

Vitale A., 'L'evoluzione dei rapporti interetnici nello spazio ex-sovietico', Futuribili, No. 1/2 (1998).

Vitale A., El Primer Israel. La increible historia del nacimiento y desarrollo de una región autónoma en un confin siberiano. De cómo el pueblo hebreo se sobrepuso a un experimento de Stalin, trans. by V. Mascioni, Buenos Aires 2007 (Conversaciones. Monde Diplomatique "El Diplö, 27).

Vitale A., La Regione ebraica in Russia. Birobidzhan, la prima Israele, Lugano 2005 (Attualità e Studi).

Waldenberg M., Kwestie narodowe w Europie Środkowo-Wschodniej. Dzieje, idee, Warszawa 1992. (Trad. ital.: Il Saggiatore, Milano 1994).

Wehler H.-U., Nationalismus. Geschichte, Formen, Folgen, München 2001 (Beck'sche Reihe, 2169).

Weinberg R., 'Birobidzhan and Solving the "Jewish Question": the Making of a Jewish Paeasantry' in Y. Ro'i (ed.), Jews and Jewish Life in Russia and the Soviet Union, Ilford 1995 (Cummings Center Series).

Weinberg R., 'Jewish Revival in Birobidzhan in the Mirror of Birobidzhanskaia Zvezda', East European Jewish Affairs, Vol. 26, No. 1 (1996).

Weinberg R., 'Purge and Politics in the Periphery: Birobidzhan in 1937', Slavic Review, Vol. 52, No. 1 (1993), at <http://dx.doi.org/10.2307/2499582>.

Weinberg R., Gitelman Z., Bradley B., Stalin's Forgotten Zion. Birobidzhan and the Making of a Soviet Jewish Homeland. An Illustrated History, 1928-1996, Berkeley 1998.

White S., Pravda A., Gitelman Z. (eds.), Developments in Russian and Post-Soviet Politics, London 1994.

Zaslavsky V., Brym R., Soviet-Jewish Emigration and Soviet Nationality Policy, New York 1983.

Albats E., Evreiskii vopros, Mosca 1995.

Bacrushin S.V., Kazaki na Amure, Leningrad 1925. 
Bruk B.L., Birobidzhan, Moscow 1928.

Bugaenko E., Na beregu Amura. 50 let Evrejskoj Avtonomnoj Oblasti, Moscow 1984.

Chavkin M.P., Evrejskaja Avtonomnaja Oblast'k svoe pervoj godovshine, Emes 1935.

Dal'nevostochnoe Otdelenie Rossijskoj Akademii Nauk (ed.), Evrejskaja Avtronomnaja Oblast': Enciklopedicheskij Slovar', Birobidzhan 1999.

Dal'nevostochnyj Federal'nyj Okrug. Shag v XXI vek, Chabarovsk 2001.

Dikij A.I., Evrei v Rossii i v SSSR. Istoricheskij ocherk, Novosibirsk 1994 (1 $1^{\text {st }}$ ed. New York 1967).

Enciklopedija Chabarovskogo Kraja i Evrejskoj Avtonmnoj Oblasti. Opyt enciklopedicheskogo-geograficheskogo slovarja, Chabarovsk 1995.

Evreiskaja Avtonomnaja Oblast', Chabarovsk 1959.

Evreiskoe Istoricheskoe Obshestvo (ed.), Istoricheskie sud'by evreev v Rossii i SSSR: nachalo dialoga. Sbornik stat'ei, Moskva 1992.

Gol'stejn M., Birobidzhancy na Amure, Mosca 1958.

Kadyshevich M., Birobidzhan - strana bol'shich vozmozhnostej, Mosca 1931.

Koblenz B., Waldheim, Mosca 1934.

Kostyrchenko G., V plenu u krasnogo faraona: politicheskie presledovania evreev v SSSR v poslednee stalinskoe desiatiletie. Dokumental'noe issledovanie, Moskva1994.

Kudish E.J., Stern - zvezda moja zavetnaja, Birobidzhan 2000.

Kurencova G.E., Ocherk rastitelnosti Evrejskoj Avt. Oblasti, Vladivostok 1967.

Leskov N.S., Evrei v Rossii: neskol'ko zamechanii po evreiskomu voprosu. Izd, Mosca 1994.

Merezhin L., Chto takoe Birobidzhan?, Mosca 1929.

RG Dal'inform, Evrejskaja Avtonomnaja Oblast'. Na rubezhe tysjacheletij, Chabarovsk 2001.

Schapiro L., Organizatsija KPSS Evrejskoj Avtonomnoj Oblasti. 1934-1985, Chabarovsk 1986.

Sergeev O.I., Kazachestvo na russkom Dal'nem Vostoke v. XVII-XIVvv., Mosca 1983.

Stolberg E.-M., 'Birobidzhan: v poiskach evrejskoj rodiny', Zhurnal Diaspory, No. 1 (1999).

Udovenko V.G., Evrejskaja Avtonomnaja Oblast', Mosca 1957.

Vaiserman D., Birobidzhan, mechti i tragedija. Istorija EAOv sudbach i dokumentach, Chabarovsk 1999.

Alessandro VITALE - is Assistant Professor of Foreign Policy Analysis / Comparative Foreign Policy and International Political Systems at the University of Milan, Italy. $\mathrm{He}$ has taught Strategic Studies, International Relations and he is a member of the Board of the Political Studies master's degree at the same University. His recent publications include L'Europa alle frontiere dell'Unione. Questioni di Geografia storica e di Relazioni Internazionali delle periferie continentali, Milan 2010. He also was Editor of the Lezioni di Scienza della Politica (Lectures in Science of Politics) of G. Miglio, Bologna, 2011. 